\title{
Effects of packed layer structure and submerged zone on nutrient removal in bioretention systems with sand, soil and fly ash
}

\author{
ZiYan Guo ${ }^{\mathrm{a}, \mathrm{b}}$, XiaoJun $\mathrm{Zuo}^{\mathrm{a}, \mathrm{b},{ }^{*},}$, Xiao $\mathrm{Wu}^{\mathrm{a}, \mathrm{b}}$, Jianghua $\mathrm{Yu}^{\mathrm{a}, \mathrm{b}}$ \\ aJiangsu Collaborative Innovation Center of Atmospheric Environment and Equipment Technology, School of \\ Environmental Science and Engineering, Nanjing University of Information Science \& Technology, Nanjing, \\ 210044, China; \\ ${ }^{\mathrm{b} J i a n g s u ~ K e y ~ L a b o r a t o r y ~ o f ~ A t m o s p h e r i c ~ E n v i r o n m e n t ~ M o n i t o r i n g ~ a n d ~ P o l l t i o n ~ C o n t r o l, ~ J i a n g s u ~ J o i n t ~ L a b o r a t o r y ~}$ \\ of Atmospheric Pollution Control, Nanjing, 210044, China
}

*Corresponding author, Email: z850108xj@163.com, Tel: 86-25-58731090, Fax: 86-25-58731090

Abstract: Both sand and fly ash were found to be promising for phosphorus removal in bioretention systems. However, nutrient removal in bioretention systems with sand, soil and fly ash was still uncertain due to a lack of data about the influence of layer structure and submerged zone. In this study, a mixture with sand, soil and fly ash (1:1:1) was selected as the base in bioretention systems with different packed layer structures and heights of submerged zone. The comparison of multi-layered structure with mixed structure implied that the used bioretention system with multi-layered structure was superior to that with mixed structure for nitrogen and phosphorus removal. The investigation of the influence of submerged zones on nutrient removal indicated that the submerged zone could significantly improve nitrate removal efficiency with $67.52 \%-86.32 \%$, while sharply reduce the removal of ammonia nitrogen (from $95.15 \%$ to $51.81 \%$ ) and TP (from $88.66 \%$ to $44.50 \%$ ). Overall evaluation of the effect of packed layer structures and submerged zones suggested that the bioretention system with multi-layered structure at the height of submerged zone at $20-40 \mathrm{~cm}$ was the most satisfactory, due to its microbial environment.

Key words: Bioretention; Fly ash; Structures; Submerged zone; Nutrient removal

\section{Introduction}

Recently, non-point source pollution has already become the importance factor causing urban water pollution, due to its strong randomness, complicated contributing factor, dispersibility etc. Urban stormwater runoff was the main component of urban non-point source pollution. There were amounts of pollutants in urban stormwater runoff generated by human activities and natural 
processes, including suspended solids, grease, organic carbon, bacteria etc (Davis et al., 2005). Bioretention was one of the best management practices (BMPs), which has been proved to be effective in controlling rainfall runoff and reducing peak flow (Davis et al., 2009).

There have been many literatures about nutrient removal in stormwater runoff by the bioretention systems. Davis et al. (2001) found that the removal of total Kjeldahl nitrogen (TKN), ammonia nitrogen $\left(\mathrm{NH}_{3}-\mathrm{N}\right)$ and total phosphorus (TP) could all get to $55-80 \%$, while the removal of TN in bioretention systems was unstable with the concentration of effluents higher even than that of inflows. Similarly, Hunt et al. (2008) reported that the removals of total nitrogen (TN), TKN, $\mathrm{NH}_{3}-\mathrm{N}$ and TP in bioretention systems were $33 \%, 44 \%, 73 \%$, and $31 \%$, respectively, but $\mathrm{NO}_{3}{ }^{-}$was hardly removed, which was in line with the results found by Hsieh et al. (2005). The release of nitrate $\left(\mathrm{NO}_{3}^{-}\right)$was one of the main reasons for low nitrogen removal (Wang et al., 2017). Thus, how to effectively remove $\mathrm{NO}_{3}{ }^{-}$could be the key for the improvement of nitrogen removal in bioretention systems.

The transformation of $\mathrm{NO}_{3}{ }^{-}$can be mainly divided into two forms: First is bioassimilation, including absorption by plants, bacteria, fungus or other microorganisms (Read et al., 2008; Payne et al., 2014), and the second is denitrification, which could change inorganic nitrogen into gaseous form $\left(\mathrm{N}_{2}\right.$ or $\mathrm{N}_{2} \mathrm{O}$ ) (Vymazal et al., 2007; Wan et al., 2017). Thereinto, denitrification process requires usually anaerobic environment and carbon source. Installing the submerged zone has been proved to be an effective method for the advancement of denitrification process. Palmer et al. (2013) found that compared with that in non-submerged zone, the removal of $\mathrm{NO}_{3}{ }^{-}$increased from $33 \%$ to $71 \%$ in bioretention systems with submerged zone, while the removal of TP decreased from $80 \%$ to $67 \%$. The simultaneous removal for both nitrogen and phosphorus should be more satisfactory when the emergence of submerged zone in bioretention systems. On the other hand, the previous literature reported that fly-ash-amended sand was obviously effective for phosphorus removal in bioretention systems (Zhang et al., 2008), which provided a potential method to make sure the phosphorus removal in bioretention systems with submerged zone. However, nitrogen removal in bioretention systems with sand and fly ash was unsatisfactory. Meanwhile, the data on the influence of stromal layer structure in the mentioned materials based bioretention systems was also deficient, due to the low permeability of fly ash. 
Therefore, there was still a need to conduct detailed investigation on the removal for both nitrogen and phosphorus in bioretention systems with sand and fly ash under different structures and heights of submerged zone. In this study, a mixture with sand, soil and fly ash (1:1:1) was selected as the base in bioretention systems with different structures and heights of submerged zone in this study. The nutrient removal under multi-layered structure was compared with that mixed structure. The influence of submerged zones on nutrient removal was investigated. Finally, overall evaluation of the effect of packed layer structures and submerged zones on nutrient removal was also made.

\section{Materials and methods}

\subsection{Preparation of bioretention columns}

Eight pilot-scale bioretention columns were designed and placed in an open field at Nanjing University of Information science \& technology, China, with number of 1-1, 1-2, 1-3, 1-4, 2-1, 2-2, 2-3, 2-4). Each bioretention column was made using the DN200 PVC pipe with 6mm thickness and $100 \mathrm{~cm}$ height. There was a $10 \mathrm{~cm}$ drain layer made by stones and pebbles at the bottom of columns. Columns (1-1, 1-2, 1-3, 1-4) were filled using a mixture with sand, soil and fly ash (1:1:1), and respectively installed with the height of the submerged zone $0 \mathrm{~cm}, 20 \mathrm{~cm}, 40 \mathrm{~cm}$ and $60 \mathrm{~cm}$. However, columns (2-1, 2-2, 2-3, 2-4) were filled under layered structure with $20 \mathrm{~cm}$ sand, $20 \mathrm{~cm}$ soil and $20 \mathrm{~cm}$ fly ash (Fig.1). There were six layers, each of which was $10 \mathrm{~cm}$ in height. They were also respectively installed with the height of the submerged zone $0 \mathrm{~cm}, 20 \mathrm{~cm}, 40 \mathrm{~cm}$ and $60 \mathrm{~cm}$.

(Figure 1)

\subsection{Pilot-scale bioretention experiments}

The conditions of simulated rainfall runoff were also designed, including number of operations, interval time inflow and concentrations of pollutants in influent. A peristaltic pump (bt100-11, China) was used to simulate rainfall events. Simulated rainfall types referred to Nanjing summer short-term heavy rainfall (Zuo et al., 2012), and the inflow concentration was set according to the quality of urban road runoff in Nanjing, China (Zuo et al., 2011).

Pilot-scale bioretention experiments were divided into two parts. The first part was to analyze 
the permeability and nutrient removing in bioretention systems without submerged zone, for the comparison between multi-layered structure and mixed structure, where the experiment was operated for 42 days with 7 days interval time of each experiment. The second part was to investigate the influence of different heights of submerged zone on nutrient removal, where the experiment was operated for 84 days with 7 days interval time of each experiment. Both nitrogen and phosphorus were determined by ion chromatography (ICS-1600, ICS-3000, and/or LC20, DIONEX).

\subsection{Analysis method}

The formula for calculating pollutant concentration removal efficiency was as follows (1):

$$
R_{C}=\frac{C_{i}-C_{o}}{C_{i}} \times 100 \%
$$

Where $R_{C}$ is the removal of pollutants (\%); $C_{i}$ is the pollutant concentration of inflow (mg/L); $C_{o}$ is the pollutant concentration of outflow $(\mathrm{mg} / \mathrm{L})$.

The permeability of the used material was measured by using the Darcy formula (2):

$$
K=\frac{V}{\left(\frac{\Delta \mathrm{h}}{L}\right) A t}
$$

Where, $\Delta \mathrm{h}$ is height difference $(\mathrm{cm}) ; \mathrm{L}$ is the seepage length $(\mathrm{cm}) ; \mathrm{A}$ is the cross-sectional perpendicular to the flow direction; $\mathrm{t}$ is time $(\mathrm{s})$; $\mathrm{V}$ is seepage water volume $(\mathrm{mL})$.

\section{Results and discussion}

\subsection{Comparison of multi-layered structure with mixed structure}

According to the Fig. 2, it could be found that when the operation was stable, the average removal of $\mathrm{NH}_{3}-\mathrm{N}$ and $\mathrm{NO}_{3}{ }^{-}$in the used bioretention systems with mixed structure were $62.75 \%$ and $50 \%$, respectively. But, the average removal of ammonia and $\mathrm{NO}_{3}{ }^{-}$in the used bioretention systems with multi-layered structure was $72.25 \%$ and $56.33 \%$, respectively. There were stable phosphorous removal efficiencies with $94 \%$ for the two mentioned structures. Compared with the found by Hunt et al. (2008), the removal of ammonia was similar, while the removal of phosphorous was significantly better with the increase of $63 \%$ in this study, which could be due to that the excellent removal ability of fly ash on phosphorus (Dhanke et al., 2018).

On the other hand, the infiltration rate of the used bioretention systems with mixed structure 
was $13.32 \mathrm{~mm} / \mathrm{h}$, while that of the used bioretention systems with multi-layered structure was 38.8 $\mathrm{mm} / \mathrm{h}$. The infiltration rate of stromwater bioretention systems should be at least $12.5 \mathrm{~mm} / \mathrm{h}$, based on the design requirements of USEPA (Coustumer et al., 2009). Although the used bioretention systems met the mentioned requirement on the infiltration rate, the permeability coefficient in the bioretention systems might drop significantly after running for a while, and there was a risk of clogging. Thus, the application of multi-layered structure could help to increase the service life of bioretention systems, suggesting the used bioretention system with multi-layered structure was superior to that with mixed structure for nitrogen and phosphorus removal.

(Figure 2)

\subsection{Effects of the submerged zone}

\subsubsection{The effect of submerged zone on ammonia nitrogen removal}

The $\mathrm{NH}_{3}-\mathrm{N}$ removal by the used bioretention systems with submerged zone reached stable after 42 days of the operation (Fig.3). When the height of submerged zone was $20 \mathrm{~cm}$, the $\mathrm{NH}_{3}-\mathrm{N}$ average removal was the best with $92.07 \%$ (the mixed structure) and $95.15 \%$ (the multi-layered structure). When the height of submerged zone increased to $40 \mathrm{~cm}$, the removal of $\mathrm{NH}_{3}-\mathrm{N}$ decreased slightly. The average removal efficiency of $\mathrm{NH}_{3}-\mathrm{N}$ was $87.05 \%$ in bioretention systems with the mixed structure, and $88.26 \%$ in bioretention systems with the multi-layered structure. The average removal efficiencies of $\mathrm{NH}_{3}-\mathrm{N}$ under the mentioned heights of submerged zone were obviously higher than that in bioretention systems with sands and carbon source at $20-30 \mathrm{~cm}$ height of submerged zone (Wang et al., 2018). However, the removal of $\mathrm{NH}_{3}-\mathrm{N}$ decreased obviously, when the height of submerged zone increased to $60 \mathrm{~cm}$, where the average removal efficiencies of $\mathrm{NH}_{3}-\mathrm{N}$ were $51.81 \%$ (the mixed structure) and 56.81\% (the multi-layered structure), respectively. It showed that removal efficiencies of $\mathrm{NH}_{3}-\mathrm{N}$ in the used bioretention systems with $20 \mathrm{~cm}$ and $40 \mathrm{~cm}$ heights of submerged zone were both obviously improved compared with that of non-submerged zone, which was in line with the one reported by Wang et al. (2018). In addition, setting submerged zone did not affect the fact that the $\mathrm{NH}_{3}-\mathrm{N}$ removal by the used bioretention systems with the multi-layered structure was slightly better than that of the mixed structure.

(Figure 3)

\subsubsection{The effect of submerged zone on nitrate removal}


In this study, the effect of submerged zone on the removal of $\mathrm{NO}_{3}^{-}$in the used bioretention systems was also investigated. The time to reach stable of $\mathrm{NO}_{3}{ }^{-}$removal in the used bioretention systems with submerged zone was the same as that of $\mathrm{NH}_{3}-\mathrm{N}$ removal (Fig. 4). There were the highest $\mathrm{NO}_{3}^{-}$removal efficiencies with $86.32 \%$ (the mixed structure) and $84.86 \%$ (the multi-layered structure) for the two mentioned structures when the height of submerged zone at $60 \mathrm{~cm}$. While, the height of submerged zone at $40 \mathrm{~cm}$, the removal of $\mathrm{NO}_{3}^{-}$showed a slight decrease with $79.44 \%$ (the mixed structure) and $77.47 \%$ (the multi-layered structure). Similarly, the removal of $\mathrm{NO}_{3}^{-}$continued to decrease obviously with $72.27 \%$ (the mixed structure) and $67.52 \%$ (the multi-layered structure) when the height of submerged zone at $20 \mathrm{~cm}$, which was lower than the one $(88 \%)$ in bioretention systems with sands and carbon source under the same height of submerged zone obtained by Wang et al. (2018), but slightly higher than that (65\%) in bioretention systems with Ottawa sand and biochar (7:3) under submerged zone (Afrooz and Alexandria, 2017). It indicated that the used bioretention systems were satisfactory in $\mathrm{NO}_{3}{ }^{-}$ removal after installing the submerged zone. Meanwhile, it implied that the submerged zone in the used bioretention systems had more obvious influence on $\mathrm{NO}_{3}{ }^{-}$removal under mixed structure than that of multi-layered structure.

(Figure 4)

\subsubsection{The effect of submerged zone on TP removal}

Compared with that of nitrogen removal, the time to reach stable of TP removal in the used bioretention systems with submerged zone was late with one week (Fig. 5). The TP removal by the used bioretention systems decreased with the increase of the height of submerged zone, which was similar to that of $\mathrm{NH}_{3}-\mathrm{N}$, but contrary to the one of $\mathrm{NO}_{3}^{-}$. Thereinto, when the height of submerged zone at $20 \mathrm{~cm}$, the average removal efficiencies of TP were $82.43 \%$ (the mixed structure) and $88.66 \%$ (the multi-layered structure), respectively. This was similar with the one (85.2-93.5\%) in the bioretention system with sand and fly ash under $15 \mathrm{~cm}$ height of submerged zone (Li et al., 2018). There were $80.58 \%$ (the mixed structure) and $81.23 \%$ (the multi-layered structure) for the average removal efficiencies of TP when the height of submerged zone at $20 \mathrm{~cm}$. When the height of submerged zone got to $60 \mathrm{~cm}$, the average removal efficiencies of TP were $46.59 \%$ (the mixed structure) and $44.50 \%$ (the multi-layered structure), respectively. The 
mentioned results indicated that submerged zone had the negative influences on the removal of TP in the used bioretention systems, compared with the case of the used bioretention systems without submerged zone, which was in line with the found obtained by Palmer et al. (2013).

(Figure 5)

\subsection{Overall evaluation of the effect of packed layer structures and submerged zones}

In this study, the $\mathrm{NH}_{3}-\mathrm{N}$ removal efficiencies were respectively $72.25 \%$ (the multi-layered structure) and $62.75 \%$ (the mixed structure) for the used bioretention systems without submerged zone. However, the removal efficiencies of the used bioretention systems with submerged zone could reach $56.81 \%-95.15 \%$ (the multi-layered structure) and $51.81 \%-92.07 \%$ (the mixed structure), respectively. The removal of $\mathrm{NH}_{3}-\mathrm{N}$ in bioretention systems mainly depended on the material adsorption and microbial metabolism (Feng et al., 2019), which resulted in the oxidation of $\mathrm{NH}_{3}-\mathrm{N}$ into $\mathrm{NO}_{3}^{-}$by nitrosating bacteria and nitrifying bacteria in the bioretention systems under aerobic condition (Chen et al., 2013). At the initial, the removal of $\mathrm{NH}_{3}-\mathrm{N}$ could depend on the physical adsorption by sand and fly ash (Nowak and Wisniowska, 2016; Du et al., 2018). And then, the microbiologic population in the used bioretention systems got to certain extent, where microbial metabolism began to dominate the removal of $\mathrm{NH}_{3}-\mathrm{N}$. More and more carbon was found in the used bioretention systems with the increase of the height of submerged zone, as well as nitrogen and phosphorus, which provided conditions for the growth of microorganisms and thus enhanced the microbial metabolism to remove $\mathrm{NH}_{3}-\mathrm{N}$. However, the content of dissolved oxygen decreased after the increasing height of submerged zone, which could inhibit the oxidation of $\mathrm{NH}_{3}-\mathrm{N}$ by nitrosating bacteria and nitrifying bacteria. The mentioned contradictory cases proved the fact that the best $\mathrm{NH}_{3}-\mathrm{N}$ removal appeared when the height of submerged zone at $20-40 \mathrm{~cm}$. Similarly, the formation of anaerobic environments due to the setting of the submerged zone resulted in the suitable conditions for the growth of denitrifying microorganisms, which was proportional to the height of submerged zone (Andrus et al., 2014). The increasing denitrifying bacteria could more effectively transform $\mathrm{NO}_{3}{ }^{-}$into $\mathrm{N}_{2}$ and $\mathrm{N}_{2} \mathrm{O}$ through denitrification (Yan et al., 2019), which was proved by the result that the removal efficiency of $\mathrm{NO}_{3}^{-}$increased with the increase of the height of submerged zone in this study. For phosphorus removal, the installation of submerged zone has a certain effect on phosphorus removal in the used bioretention systems, 
which may be caused by the biological absorption. The anaerobic environment increased with the increase of submerged zone in the used bioretention systems, which was not conducive to the uptake of phosphorus by microorganisms. For example, polyphosphate accumulating organisms (PAOs), which was one of the most important microorganisms for TP removal, could be negatively impacted by the anaerobic environment (Qiu et al., 2019). On the other hand, as the increase of the height of submerged zone, the phosphorus absorbed by the used materials may be released under appropriate water quality conditions, which may be another reason. In general, the mentioned hypotheses about the role of microbial metabolism in the used bioretention systems needed further to be proved through finding out diversity and metabolism of microorganisms in bioretention systems with sand, soil and fly ash, which could accurately reveal effects of structure and submerged zone on nutrient removal, and then draw up the feasible methods to improve the nutrient removal.

\section{Conclusions}

Bioretention system with sand, soil and fly ash was found to be significantly influenced by the packed layer structure and submerged zone for the nutrient removal. The used bioretention system with multi-layered structure was superior to that with mixed structure for nitrogen and phosphorus removal. Meanwhile, the submerged zone could significantly improve $\mathrm{NO}_{3}{ }^{-}$removal efficiency with $67.52 \%-86.32 \%$, but sharply reduce the removal of $\mathrm{NH}_{3}-\mathrm{N}$ (from $95.15 \%$ to $51.81 \%$ ) and TP (from $88.66 \%$ to $44.50 \%$ ). The multi-layered structured bioretention system with the height of submerged zone at $20-40 \mathrm{~cm}$ led to the most satisfactory results with the removal efficiencies of $\mathrm{NH}_{3}-\mathrm{N}, \mathrm{NO}_{3}{ }^{-}$and $\mathrm{TP}$ accounted respectively for $88.26 \%, 77.47 \%$ and $81.23 \%$, due to its microbial environment. Both diversity and metabolism of microorganisms in bioretention systems with sand, soil and fly ash should be further considered to draw up the feasible methods to improve the nutrient removal.

\section{Acknowledgments}

This work was supported by a grant from the project of 'Jiangsu Specially-Appointed Professor' (1421071801005) and 'Project support for excellent graduation thesis (Design) of undergraduate 
students in Nanjing University of Information Science \& Technology’.

\section{References}

Afrooz ARMN, Alexandria BB. Effects of submerged zone, media aging, and antecedent dry period on the performance of biochar-amended biofilters in removing fecal indicators and nutrients from natural stormwater. Ecological Engineering, 2017, 102, 320-330.

Andrus JM, Porter MD, Rodriguez LF, Kuehlhorn T, Cooke RAC, Zhang YH, et al. Spatial variation in the bacterial and denitrifying bacterial community in a biofilter treating subsurface agricultural drainage. Microbial Ecology, 2014, 67, 265-272.

Chen XL, Peltier E, Sturm BSM, Young CB. Nitrogen removal and nitrifying and denitrifying bacteria quantification in a stormwater bioretention system. Water Research, 2013, 47(4), $1691-1700$.

Davis AP, Hunt WF, Traver RG, Clar M. Bioretention Technology: Overview of Current Practice and Future Needs. Journal of Environmental Engineering, 2009, 135, 109-117.

Davis AP, Mccuen RH. Stormwater management for smart growth. New York: Springer, 2005, $136-141$.

Davis AP, Shokouhian M, Shanna H, Minami C. Laboratory study of biological retention for urban stormwater management. Water Environment Research, 2001, 73, 5-14.

Dhanke P, Patil A, Kore V, Thakare P, Patil U, Wagh S. Phosphate removal from industrial wastewater effluent using modified coal fly ash. Desalination and Water Treatment, 2018, 116, $232-241$.

Du L, Trinh X, Chen QR, Wang C, Liu SY, Liu PP, et al. Effect of clinoptilolite on ammonia emissions in integrated vertical-flow constructed wetlands (IVCWs) treating swine wastewater. Ecological Engineering, 2018, 122, 153-158.

Feng F, Liu ZG, Song YX, Jiang CK, Chai XL, Tang CJ, et al. The application of aged refuse in nitrification biofilter: Process performance and characterization. Science of the Total Environment, 2019, 657, 1227-1236.

Hsieh CH, Davis AP. Evaluation and optimization of bioretention media for treatment of urban storm water runoff. Journal of Environmental Engineering, 2005, 131, 1521-1531. 
Hunt WF, Smith JT, Jadlocki SJ, Hathaway JM, Eubanks PR. Pollutant removal and peak flow mitigation by a bioretention cell in urban charlotte, N.C. Journal of Environment Engineering, 2008, 134, 403-408.

Le Coustumer S, Fletcher TD, Deletic A, Barraud S, Lewis JF. Hydraulic performance of biofilter systems for stormwater management: Influences of design and operation. Journal of Hydrology, 2009, 376, 16-23.

Li JK, Zheng L, Li YJ, Li P, Jiang CB. Experimental study and simulation of phosphorus purification effects of bioretention systems on urban surface runoff. Plos One, 2018, 13, 1-18.

Matson PA, McDowell WH, Townsend AR, Vitousek PM. The globalization of N deposition: Ecosystem consequences in tropical environments. Biogeochemistry, 1999, 46, 67-83.

Nowak R, Wisniowska E. Effect of mechanical activation of fly ashes on selected pollutants removal from landfill leachates. Desalination and Water Treatment, 2016, 57, 1050-1057.

Palmer ET, Poor CJ, Hinman C, Stark JD. Nitrate and phosphate removal through enhanced bioretention media: mesocosm study. Water Environment Research, 2013, 85(9), 823-832.

Payne EGI, Fletcher TD, Russell DG, Grace MR, Cavagnaro TR, Evard V, et al. Temporary storage or permanent removal? The division of nitrogen between biotic assimilation and denitrification in stormwater biofiltration systems. Plos One. 2014, 9, e90890.

Qiu GL, Zuniga-Montanez R, Law YY, Thi SS, Nguyen TQN, Eganathan K. Polyphosphate-accumulating organisms in full-scale tropical wastewater treatment plants use diverse carbon sources. Water Research, 2019, 149, 496-510.

Read J, Wevill T, Fletcher TD, Deletic A. Variation among plant species in pollutant removal from stormwater in biofiltration system. Water Research, 2008, 42, 893-902.

Vymazal J. Removal of nutrients in various types of constructed wetlands. Science of the Total Environment, 2007, 380(1-3), 48-65.

Wan ZX, Li T, Shi ZB. A layered bioretention system for inhibiting nitrate and organic matters leaching. Ecological Engineering, 2017, 107, 233-238.

Wang M, Zhang DQ, Li Y, Hou QH, Yu YY, Qi JD, et al. Effect of a submerged zone and carbon source on nutrient and metal removal for stormwater by bioretention Cells. Water, 2018, 10, 1629. 
Wang SM, Lin XY, Yu H, Wang ZD, Xia HX, An JS, et al. Nitrogen removal from urban stormwater runoff by stepped bioretention systems. Ecological Engineering, 2017, 106, 340-348.

Yan LL. Liu S, Liu QP, Zhang MY, Liu Y, Wen Y, et al. Improved performance of simultaneous nitrification and denitrification via nitrite in an oxygen-limited SBR by alternating the DO. Bioresource Technology, 2019, 275, 153-162.

Zhang W, Glenn OB, Daniel ES, Zhang HL. Fly-ash-amended sand as filter media in bioretention cells to improve phosphorus removal. Water Environment Research, 2008, 80(6), 507-516.

Zuo XJ, Fu DF, Li H. Distribution characteristics of pollutants and their mutual influence in highway runoff. Clean-Soil, Air, Water, 2011, 39, 956-963.

Zuo XJ, Fu DF, Li H. Speciation distribution and mass balance of copper and zinc in urban rain, sediments, and road runoff. Environmental Science and Pollution Research, 2012, 19, 4042-4048.

\section{Figure Captions}

Fig. 1 Pilot-scale bioretention columns

Fig. 2 Nutrient removal by the used bioretention systems without submerged zone: (a) mixed structure and (b) multi-layered structure

Fig. $3 \mathrm{NH}_{3}-\mathrm{N}$ removal by the used bioretention systems with submerged zone: (a) mixed structure and (b) multi-layered structure

Fig. $4 \mathrm{NO}_{3}{ }^{-}$removal by the used bioretention systems with submerged zone: (a) mixed structure and (b) multi-layered structure

Fig. 5 TP removal by the used bioretention systems with submerged zone: (a) mixed structure and (b) multi-layered structure 


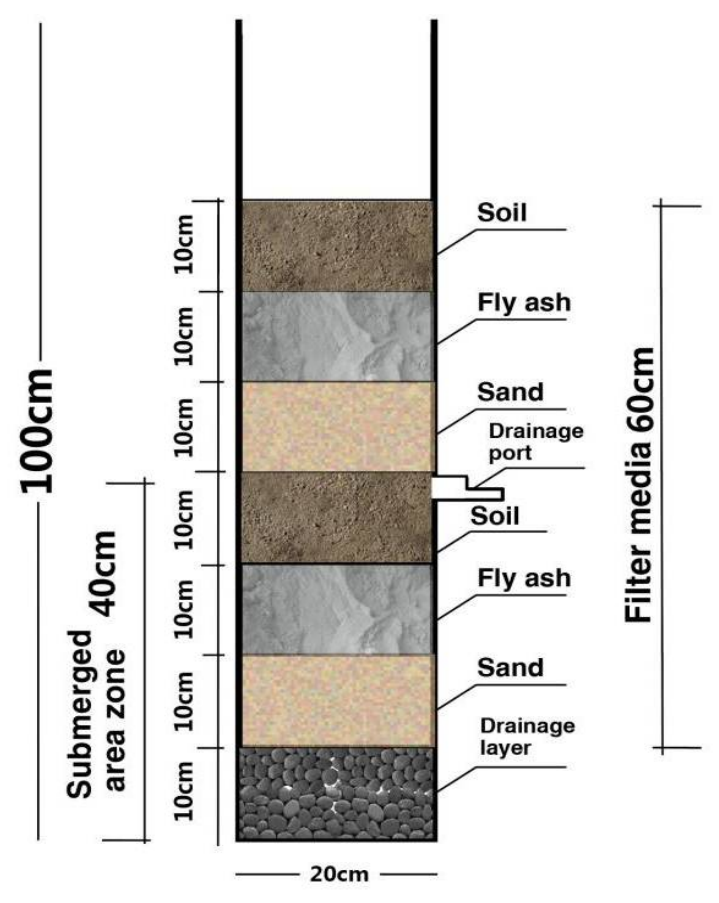

Figure 1 

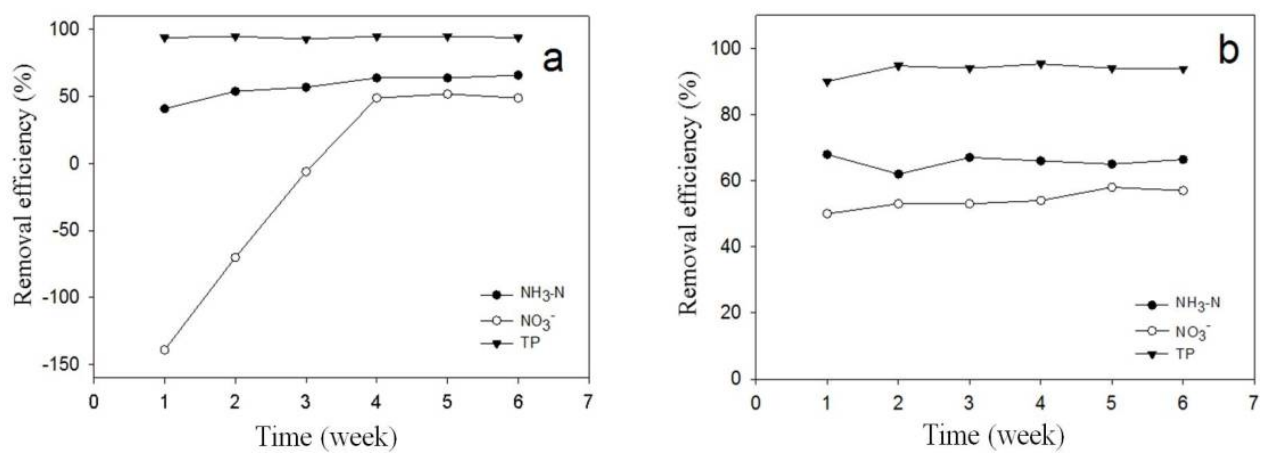

Figure 2 

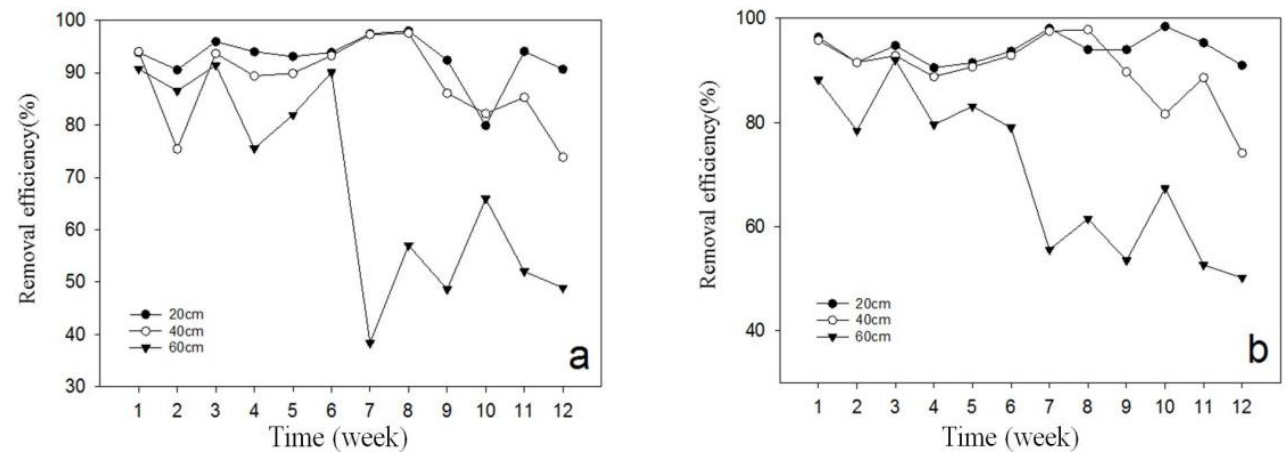

Figure 3 

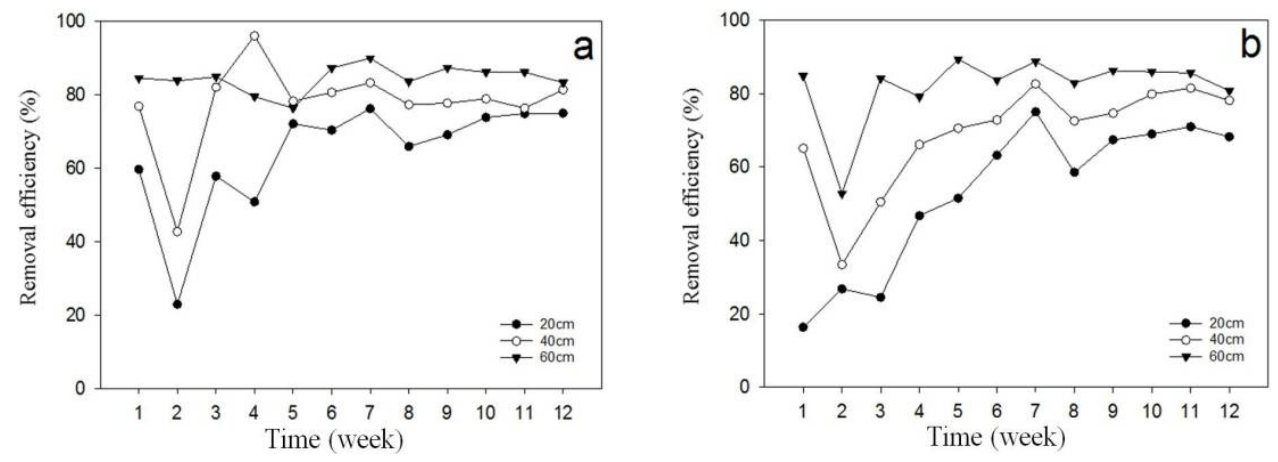

Figure 4 

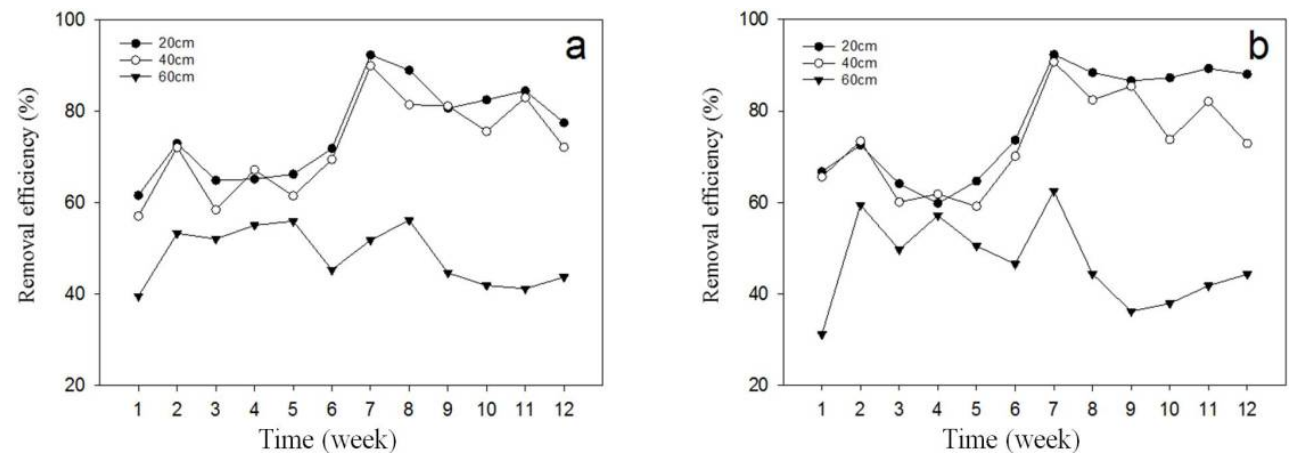

Figure 5 